\title{
Dexamethasone Downregulates Endothelin Receptors and Reduces Endothelin-Induced Production of Matrix Metalloproteinases in Cultured Rat Astrocytes $\$$
}

\author{
Yutaka Koyama, Ayano Ukita, Kana Abe, Kuniaki Iwamae, Shogo Tokuyama, \\ Keisuke Tanaka, and Yuki Kotake \\ Laboratory of Pharmacology, Faculty of Pharmacy, Osaka Ohtani University, Tonda-bayashi, Osaka, Japan (Y.Koy., A.U., K.A., \\ K.I., K.T., Y.Kot.); and Department of Clinical Pharmacy, School of Pharmaceutical Sciences, Kobe Gakuin University, \\ Minatojima, Kobe, Japan (S.T.)
}

Received October 27, 2016; accepted April 25, 2017

\section{ABSTRACT}

In brain disorders, astrocytes change phenotype to reactive astrocytes and are involved in the induction of neuroinflammation and brain edema. The administration of glucocorticoids (GCs), such as dexamethasone (Dex), reduces astrocytic activation, but the mechanisms underlying this inhibitory action are not well understood. Endothelins (ETs) promote astrocytic activation. Therefore, the effects of Dex on ET receptor expressions were examined in cultured rat astrocytes. Treatment with $300 \mathrm{nM}$ Dex for 6-48 hours reduced the mRNA expression of astrocytic $E T_{A}$ and $E T_{B}$ receptors to $30-40 \%$ of nontreated cells. Levels of $\mathrm{ET}_{\mathrm{A}}$ and $\mathrm{ET}_{\mathrm{B}}$ receptor proteins became about $50 \%$ of nontreated cells after Dex treatment. Astrocytic $\mathrm{ET}_{\mathrm{A}}$ and $\mathrm{ET}_{\mathrm{B}}$ receptor mRNAs were decreased by $300 \mathrm{nM}$ hydrocortisone. The effects of Dex and hydrocortisone on astrocytic ET receptors were abolished in the presence of mifepristone, a GC receptor antagonist. Although Dex did not decrease the basal levels of matrix metalloproteinase (MMP) 3 and MMP9 mRNAs, pretreatment with Dex reduced ET-induced increases in MMP mRNAs. The effects of ET-1 on the release of MMP3 and MMP9 proteins were attenuated by pretreatment with Dex. ET-1 stimulated the phosphorylation of extracellular signal-regulated kinase 1/2 (ERK1/2) in cultured astrocytes. Pretreatment with Dex reduced the ET-induced increases in ERK1/2 phosphorylation. In contrast, pretreatment with Dex did not affect MMP production or ERK1/2 phosphorylation induced by phorbol myristate acetate, a protein kinase $\mathrm{C}$ activator. These results indicate that Dex downregulates astrocytic ET receptors and reduces ET-induced MMP production.

\section{Introduction}

Glucocorticoids (GCs), such as dexamethasone (Dex), have various pharmacological actions, including antiinflammation, immunosuppression, anabolism, and fluid homeostasis, and are widely used in the clinic. Studies using animal models reported that GCs prevented the impairment of nerve functions by intracerebral hemorrhage (Yang et al., 2011; Lee et al., 2015), nerve trauma (Holmin and Mathiesen, 1996; Genovese et al., 2007), or brain tumor (Gu et al., 2009; Fan et al., 2014), by preventing disruption of the blood-brain barrier (BBB), neuroinflammation, and brain edema. Based on these findings, clinical trials to examine the beneficial actions of GCs were undertaken for patients with spinal cord injury (Bracken et al., 1990, 1997) or brain tumor (Piette et al., 2006). However, the beneficial actions of GCs are still

This work was supported by a Grant-in-Aid for Scientific Research (C) from the Japan Society for the Promotion of Science [Grant 15K07981].

No potential conflicts of interest relevant to this article are reported.

https://doi.org/10.1124/mol.116.107300.

S This article has supplemental material available at molpharm. aspetjournals.org. controversial (Nichols et al., 2005). Thus, further investigation of the actions of GCs in brain disorders is required.

Astrocytes play an important role in the induction of various pathophysiological responses in injured nerve tissues. During brain disorders, astrocytes change phenotype to reactive astrocytes, which are characterized by hypertrophy of the cell body and the increased expression of glial fibrillary acidic protein (GFAP) (Koyama, 2014). Accompanying the phenotypic conversion, astrocytes produce various soluble factors that affect the functions of other brain cells and modulate pathophysiological responses (Buffo et al., 2010; Burda et al., 2016). Because these astrocyte-derived factors include proinflammatory substances and vascular permeability factors, the induction of reactive astrocytes aggravates nerve injury mediated by neuroinflammation and brain edema (Lopes Pinheiro et al., 2016; Stokum et al., 2016). Astrocytic GC receptors are upregulated by brain injury (Yan et al., 1999; Hwang et al., 2006), and GCs were suggested to affect the pathophysiological functions of astrocytes. In animal models of brain injury, the administration of Dex prevented the induction of GFAP-positive reactive astrocytes (Imai et al.,

ABBREVIATIONS: ANOVA, analysis of variance; BBB, blood-brain barrier; Dex, dexamethasone; ECE, endothelin-converting enzyme; ERK, extracellular signal-regulated kinase; ET, endothelin; G3PDH, glycerol-3-phosphate dehydrogenase; GC, glucocorticoid; GFAP, glial fibrillary acidic protein; MEM, minimal essential medium; MMP, matrix metalloproteinase; PKC, protein kinase C; PMA, phorbol 12-myristate 13-acetate. 
TABLE 1

Comparison of the mRNA copy numbers of ET ligands, ECEs and ET receptors in cultured rat astrocytes.

\begin{tabular}{|c|c|c|}
\hline \multicolumn{3}{|c|}{ mRNA copy number $\left(\times 10^{3} / \mu \mathrm{g}\right.$ total RNA $)$} \\
\hline Prepro-ET-1 & $126.0 \pm 20.7$ & (9) \\
\hline Prepro-ET-3 & $1.21 \pm 1.32$ & (9) \\
\hline ECE1 & $1781.6 \pm 1077.6$ & (9) \\
\hline ECE2 & $499.2 \pm 141.0$ & (9) \\
\hline $\mathrm{ET}_{\mathrm{A}}$ receptor & $604.2 \pm 261.3$ & (9) \\
\hline $\mathrm{ET}_{\mathrm{B}}$ receptor & $7072.1 \pm 4041.2$ & (12) \\
\hline G3PDH & $39,834.3 \pm 30,545.0$ & (12) \\
\hline
\end{tabular}

Cultured astrocytes were prepared from the cerebra of Wistar rats, and total RNA was extracted. The mRNA copy numbers of ET ligands, ECEs, and ET receptors were determined by quantitative reverse-transcription polymerase chain reaction. The copy numbers of G3PDH mRNA in the same samples were also determined. The data are the mean \pm SD and are presented as $\times 10^{3}$ copy numbers $/ \mu \mathrm{g}$ total RNA. Numbers of total RNA preparations are given in parentheses.

2001; Spataro et al., 2005; Unemura et al., 2012). Dex also reduced brain edema formation and the infiltration of inflammatory cells in damaged brain areas (Holmin and Mathiesen, 1996; Genovese et al., 2007; Yang et al., 2011; Lee et al., 2015). In addition to its actions on inflammatory cells and brain microvessels, GCs inhibit brain edema and neuroinflammation by attenuating astrocytic activation. However, the mechanisms underlying the inhibitory actions of GCs on astrocytic activation are poorly understood.

In brain disorders, the production of endothelin (ET)-1 is increased in damaged nerve tissues, and increases in brain ET-1 modulate various pathophysiological responses of the brain (Koyama and Michinaga, 2012). Receptors for ETs, especially $\mathrm{ET}_{\mathrm{B}}$, are highly expressed in astrocytes (Peters et al., 2003; Rogers et al., 2003; Wilhelmsson et al., 2004). The administration of a selective $\mathrm{ET}_{\mathrm{B}}$ agonist increased the number of GFAP-positive reactive astrocytes in rat brain (Ishikawa et al., 1997; Koyama et al., 2003). Furthermore, $\mathrm{ET}_{\mathrm{B}}$ antagonists reduced the induction of reactive astrocytes in animal models of brain injury (Koyama et al., 1999; Gadea et al., 2008; Michinaga et al., 2014). These observations indicate that the activation of astrocytic ET receptors promotes the phenotypic conversion to reactive astrocytes. In addition, the activation of ET receptors stimulated the production of astrocytic factors that affect vascular permeability and neuroinflammation, including matrix metalloproteinases (MMPs) (Koyama and Tanaka, 2008, 2010; Koyama et al., 2011, 2012, 2013). Because the excessive production of MMPs disrupts the $\mathrm{BBB}$, the activation of astrocytic ET receptors is thought to promote brain edema formation in injured nerve tissues. In support of this, ET antagonists ameliorated the disruption of the $\mathrm{BBB}$ and brain edema formation in several types of brain injury (Moldes et al., 2012; Kim et al., 2013; Michinaga et al., 2014). Thus, GCs and ET-1 have opposing roles in the regulation of astrocytic functions, but interactions between GC and ET signals in astrocytes have not been reported. To clarify the mechanisms underlying the inhibitory action of GCs on astrocytic functions, the present study examined the effects of Dex on the expressions of ET-related molecules in cultured rat astrocytes. We report that Dex decreased astrocytic $\mathrm{ET}_{\mathrm{A}}$ and $\mathrm{ET}_{\mathrm{B}}$ receptor expression and that the downregulation of ET receptors was accompanied by a reduction of MMP3 and MMP9 production by ET-1.

\section{Materials and Methods}

Preparation of Primary Cultured Astrocytes from Rat Brain. All experimental protocols conformed to the Guide for the
Care and Use of Laboratory Animals by the U.S. National Institutes of Health and were approved by the Animal Experiment Committee of Osaka Ohtani University. Astrocytes were prepared from the cerebra of 1- to 2-day-old Wistar mixed rats as described previously (Koyama et al., 2012). Isolated cells were seeded at $1 \times 10^{4}$ cells $/ \mathrm{cm}^{2}$ in $75-\mathrm{cm}^{2}$ culture flasks and were grown in minimal essential medium (MEM) supplemented with $10 \%$ fetal calf serum. To remove small processbearing cells (mainly oligodendrocyte progenitors and microglia from the protoplasmic cell layer), the culture flasks were shaken at $250 \mathrm{rpm}$ overnight, 10-14 days after seeding. The monolayer cells were trypsinized and seeded on 6 -well culture plates or 6 -cm culture dishes. At this stage, approximately $95 \%$ of the cells showed immunoreactivity for GFAP.

Treatment of Cultured Astrocytes with GCs and ET-1. Before treatment with GCs, astrocytes in 6-well culture plates were incubated in serum-free MEM for 24 hours. Dex (Nacalai Tesque, Osaka, Japan) and hydrocortisone (Nacalai Tesque) were dissolved in dimethylsulfoxide to make stock solutions. After the culture medium was replaced with fresh serum-free MEM, an aliquot of Dex or hydrocortisone solution was added to the medium. For controls, an equal amount of dimethylsulfoxide was added. Then, astrocytes were treated for the time indicated at $37^{\circ} \mathrm{C}$. In some experiments, astrocytes treated with Dex were further treated with ET-1 (Peninsula Laboratory, Inc., Belmont, CA) or phorbol 12-myristate 13-acetate (PMA; Sigma-Aldrich, St. Louis, MO), where Dex-containing MEM was replaced with flesh serum-free MEM. After treatment with the agents, cultured astrocytes were rinsed with ice-cold phosphatebuffered saline and were used to prepare total RNA and cell lysates.

Measurement of mRNA Levels by Quantitative ReverseTranscription Polymerase Chain Reaction. Total RNA in cultured astrocytes was extracted using a total RNA extraction kit (Favorgen Biotech Corp., Ping-Tung, Taiwan). First-strand cDNA was synthesized from total RNA $(1 \mu \mathrm{g})$ using moloney murine leukemia virus reverse transcriptase (200 U; Invitrogen, Carlsbad, $\mathrm{CA})$, random hexanucleotides (0.2 $\mu \mathrm{g}$; Invitrogen) and an RNase inhibitor (20 U; Takara, Tokyo, Japan) in $10 \mu$ l of a buffer supplied by the enzyme manufacturer. mRNA levels of ET-related signal molecules in each sample were determined by quantitative polymerase chain reaction using SYBR Green fluorescent probes. Each reverse transcription product was added to Sybr Green Master Mix (Toyobo, Tokyo, Japan) along with the primer pairs, and the mixture was then placed in a thermal cycler (Opticom 2; Bio-Rad, Hercules, CA). The following primer pairs were used: preproET-1, 5'-TGTGTCTACTTCTGCCACCT-3' and 5'-CACCAGCTGCTGATAGATAC-3'; preproET-3, 5' -GGGACCAGGAGGAAAAGAGGGTG-3' and 5'- ACTGGGAACTTTCTGGAACTGG-3'; ET-converting enzyme (ECE) 1, 5'-GAGAAGCGCCGGGATGA- ${ }^{\prime}$ ' and $5^{\prime}$-GGCATTCAGAAAGGGTAACCAG-3'; ECE2, 5'-AATGAAATCGTCTTCC-3' and 5'-GTGAGTGACTCATTC-3'; ET $_{\mathrm{A}}$ receptor, 5'-TGCCCTCAGCGAACACC-3' and 5'-CATAGACGGTTTTCTTCAAA-3'; ET $_{\mathrm{B}}$ receptor, 5'-GATACGACAACTTCCGCTCCA-3' and $5^{\prime}$ - GTCCACGATGAGGACAATGAG-3'; MMP2, 5'-CTATTCTGTCAGCACTTTGG-3' and 5'-CAGACTTTGGTTCTCCAACTT-3'; MMP3, 5'-GAGGACAAATTCTGGAGATTTGATG- ${ }^{\prime}$ ' and $5^{\prime}$-GTGAAGATCCGCTGAAGAAGTAAAG $-3^{\prime}$; MMP9, 5'-AAATGTGGGTGTACACAGGC-3' and 5'-TTCACCCGGTTGTGGAAACT-3'; and glycerol-3-phosphate dehydrogenase (G3PDH), 5'-CTCATGACCACAGTCCATGC-3' and 5'-TACATTGGGGGTAGGAACAC-3'.

As a standard for the copy numbers of polymerase chain reaction products, serial dilutions of each amplicon were amplified in the same manner. The amount of mRNA was calculated as the copy number of each reverse-transcription product equivalent to $1 \mu \mathrm{g}$ of total RNA and normalized to the value for G3PDH.

Measurement of Protein Levels by Immunoblotting. Cultured astrocytes in 6-well culture plates were dissolved in $100 \mu \mathrm{l}$ of icecold homogenization buffer (20 mM Tris/HCl, pH 7.4, $1 \%$ SDS, $2 \mathrm{mM}$ ethylene-diaminetetra acetic acid, $2 \mathrm{mM}$ phenylmethylsulfonyl fluoride, $20 \mu \mathrm{g} / \mathrm{ml}$ aprotinin) at $4^{\circ} \mathrm{C}$. The lysates were centrifuged at 
$15,000 \mathrm{~g}$ for 10 minutes, and the protein contents of the supernatants were measured. The cell lysates were applied to SDS-PAGE and electroblotted onto polyvinylidene fluoride membranes. For the detection of $\mathrm{ET}_{\mathrm{A}}$ and $\mathrm{ET}_{\mathrm{B}}$ receptor proteins, the membranes were first probed with rabbit anti-ET $\mathrm{A}_{\mathrm{A}}$ receptor (1:1000 dilution; H-60; Santa Cruz Biotechnology, Santa Cruz, CA) and rabbit anti-ET $\mathrm{B}_{\mathrm{B}}$ receptor (1:4000 dilution; M-74; Santa Cruz Biotechnology), respectively. Then, membranes were incubated with peroxidase-conjugated secondary antibodies. The exposed X-ray films were scanned, and the densities of the protein bands were measured using ImageJ version 1.45 software (NIH, Bethesda, MD). After the detection of ET receptor proteins, the membranes were reprobed with mouse anti- $\beta$-actin primary antibody (1:4000 dilution; Chemicon, Temecula, CA) and the protein bands were quantified. Expression levels of ET receptor proteins were determined as a ratio to $\beta$-actin proteins. To detect the phosphorylation levels of extracellular signal-regulated kinase 1/2 (ERK1/2), the membranes were first probed with rabbit anti-phospho-ERK1/2
(1:4000 dilution; Cell Signaling Technology, Danvers, MA) and reprobed with rabbit anti-ERK1/2 (1:4000 dilution; Cell Signaling Technology). Levels of protein phosphorylation were indicated as a ratio of phosphorylated ERK1/2 protein to total ERK1/2 protein.

Determinations of MMP3 and MMP9 Protein Release by Enzyme-Linked Immunosorbent Assay. Cultured astrocytes in 6-cm culture dishes were treated with Dex and ET-1 in serum-free MEM. The concentrations of MMP3 and MMP9 proteins in the culture medium were measured by enzyme-linked immunosorbent assay kits for rat MMP3 (Cloud-Clone Corp., Houston, TX) and rat MMP9 (R\&D Systems, Minneapolis, MN) according to the supplier protocols. After the culture medium was collected, astrocytes in 6-cm dishes were dissolved with $0.1 \mathrm{~N} \mathrm{NaOH}$. The cell lysate was used to determine the total protein content. The amount of released MMP3 and MMP9 protein in culture medium was normalized to the total protein content of each dish.

Statistical Analysis. Results are presented as the mean \pm S.D. Results were analyzed by one-way analysis of variance (ANOVA)
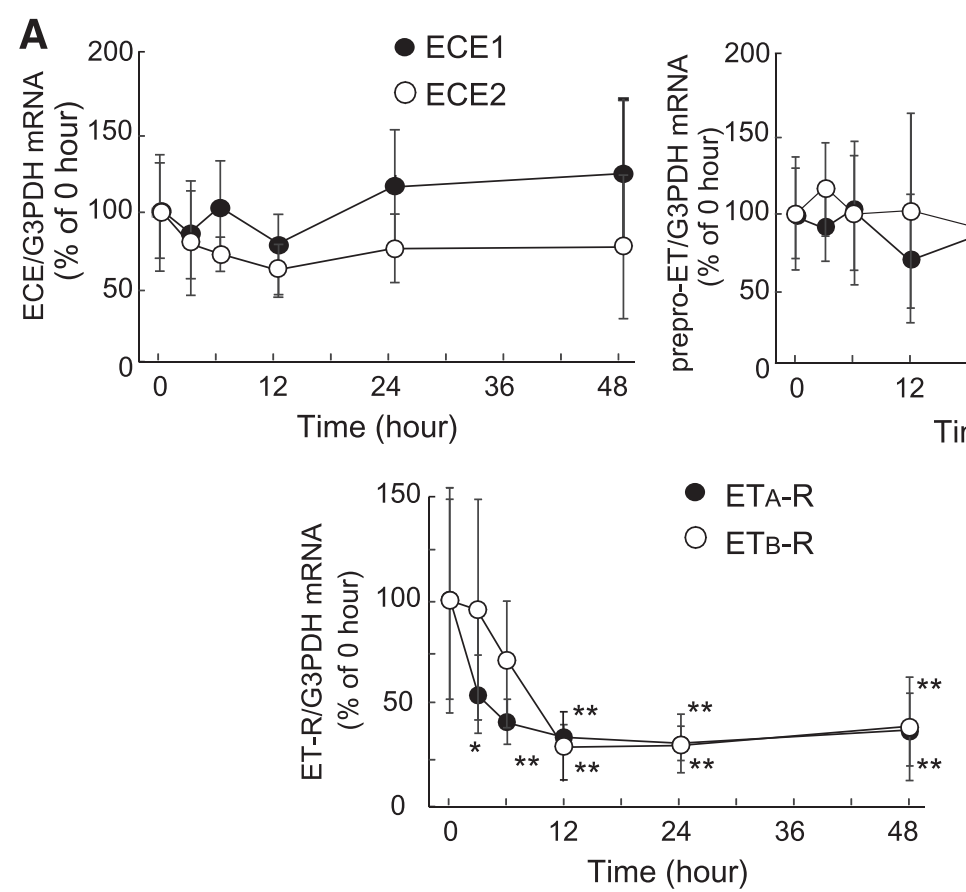

B
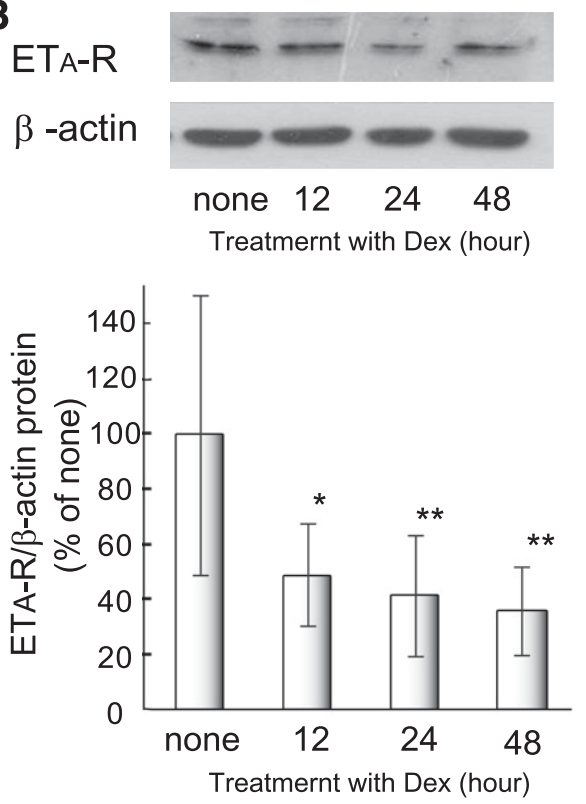

Treatmernt with Dex (hour)

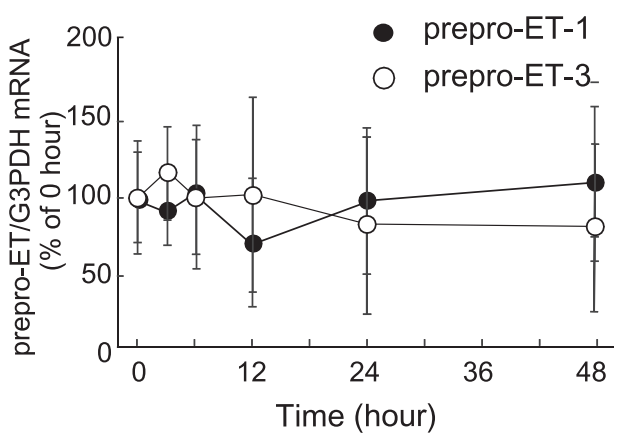

- eTA-R

ETB-R
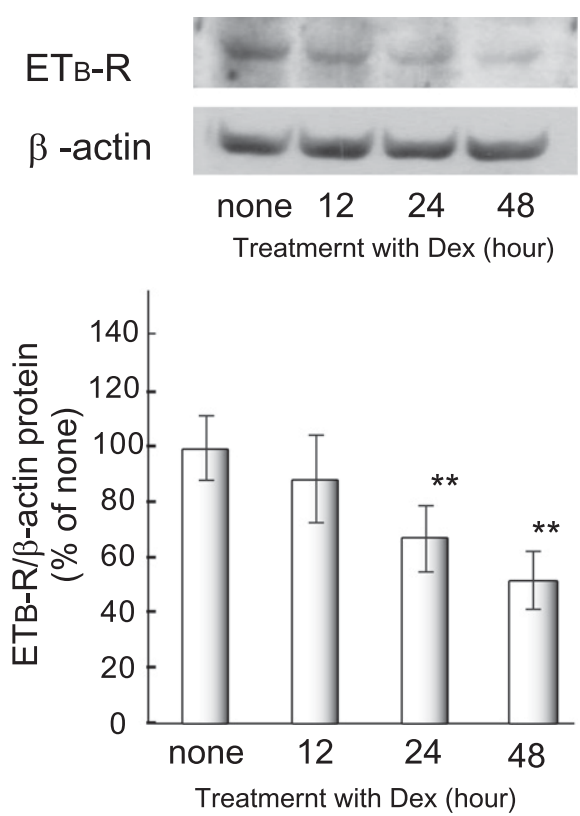

Fig. 1. (A) Effects of Dex on ECE, ET ligand, and ET receptor mRNA expression in cultured rat astrocytes. Cultured rat astrocytes were treated with $300 \mathrm{nM}$ Dex for the times indicated. The expression levels of ECE, preproET, and ET receptor (ET-R) mRNAs were normalized to that of G3PDH. The results are expressed as the mean \pm SD of 8-12 experiments. Dex caused statistically significant decreases in $\mathrm{ET}_{\mathrm{A}}$ receptor $\left(\mathrm{ET}_{\mathrm{A}}-\mathrm{R}\right)$ and $\mathrm{ET}_{\mathrm{B}}$ receptor $\left(\mathrm{ET}_{\mathrm{B}}-\mathrm{R}\right)$ mRNAs. Expression levels of $\mathrm{ET}_{\mathrm{A}}-\mathrm{R}$ mRNA in Dex treatment for 12 and 24 hours were $29.5 \%$ [95\% confidence interval (CI) $16.6-42.4 \%$ ] and $26.1 \%$ (95\% CI $15.7-36.5 \%)$ of 0 time, respectively. Expression levels of $\mathrm{ET}_{\mathrm{B}}-\mathrm{R}$ mRNA in Dex treatment for 24 and 48 hours were $30.8 \%$ (95\% CI $19.3-42.3 \%$ ) and $31.4 \%$ (95\% CI $26.8-36.0 \%$ ) of 0 time, respectively. $* P<0.05, * * P<0.01$ versus 0 time by one-way ANOVA followed by Dunnett's test. (B) Effects of Dex on levels of ET receptor proteins in cultured astrocytes. Cultured astrocytes were treated with $300 \mathrm{nM}$ Dex for 12, 24, and 48 hours. The levels of ET-R proteins were measured by immunoblotting. After the detection of ET-Rs, blots were reprobed by an anti- $\beta$-actin antibody to confirm that equal amounts of protein were loaded in each lane. Typical patterns of immunoblots for $\mathrm{ET}_{\mathrm{A}}-\mathrm{Rs}$ and $\mathrm{ET}_{\mathrm{B}}$-Rs are indicated above the graphs. The graphs show the densitometric analysis of $\mathrm{ET}_{\mathrm{A}}$ and $\mathrm{ET}_{\mathrm{B}}$ receptor proteins. The results are shown as the mean \pm SD of six to seven different preparations and are presented as ET-R/ $\beta$-actin protein ratios. Dex caused statistically significant decreases in $\mathrm{ET}_{\mathrm{A}}-\mathrm{R}$ and $\mathrm{ET}_{\mathrm{B}}-\mathrm{R}$ proteins. Expression levels of $\mathrm{ET}_{\mathrm{A}}-\mathrm{R}$ protein in Dex treatment for 24 and 48 hours were $41.5 \%$ (95\% CI $23.0-60.0 \%)$ and $35.5 \%$ (95\% CI $22.0-49.1 \%$ ) of none, respectively. Expression levels of $\mathrm{ET}_{\mathrm{B}}-\mathrm{R}$ protein in Dex treatment for 24 and 48 hours were $75.5 \%$ (95\% CI $64.8-86.2 \%$ ) and $57.4 \%$ (95\% CI $47.5-67.2 \%)$ of none, respectively. $* P<0.05, * * P<0.01$ versus none by one-way ANOVA followed by Dunnett's test. 
followed by post hoc analysis. $P$ values were calculated using EkuseruToukei2015 version 1.02 (Social Survey Research Information Co., Ltd, Tokyo, Japan). $P$ values less than 0.05 were considered to be statistically significant.

\section{Results}

Expression Levels of ET Ligands, ECEs, and ET Receptors in Cultured Rat Astrocytes. Astrocytes, the major target cells of brain ETs, produce and release ET ligands. First, we investigated the expression levels of ET signal-related molecules (i.e., ET ligands, ECEs, and ET receptors in cultured astrocytes). In nontreated astrocytes, mRNAs for preproET-1 and preproET-3 were detected, and the copy number of prepro-ET-1 was about 100 times higher than that of prepro-ET-3 (Table 1). ECEs are a peptidase family that process ET precursor peptides (i.e., big ETs) to bioactive mature ETs. Copy numbers of ECE1 and ECE2 in cultured astrocytes were similar. Although both $\mathrm{ET}_{\mathrm{A}}$ and $\mathrm{ET}_{\mathrm{B}}$ receptor mRNAs were detected in cultured astrocytes, the copy number of $\mathrm{ET}_{\mathrm{B}}$ receptors was about 10 times higher than that of $\mathrm{ET}_{\mathrm{A}}$ receptors.

Effects of Dex on the Expression of ET SystemRelated Molecules. Treatment with $300 \mathrm{nM}$ Dex for 3-48 hours had no obvious effect on the expression of preproET-1, preproET-3, ECE1, or ECE2 mRNAs in cultured rat astrocytes (Fig. 1A). $\mathrm{ET}_{\mathrm{A}}$ receptor mRNA expression was decreased by treatment with Dex for 3 hours and became about $30 \%$ of nontreated cells in 12-28 hours. $\mathrm{ET}_{\mathrm{B}}$ receptor mRNA expression was also decreased to $30-40 \%$ of the nontreated cells by treatment with Dex for 12-48 hours. Immunoblot analysis showed that Dex decreased protein levels of $\mathrm{ET}_{\mathrm{A}}$ and $\mathrm{ET}_{\mathrm{B}}$ receptors in cultured astrocytes (Fig. 1B). Decreases in ET receptor mRNAs by Dex were dose dependent, and statistically significant decreases in $\mathrm{ET}_{\mathrm{A}}$ and $\mathrm{ET}_{\mathrm{B}}$ receptors were obtained at concentrations greater than $30 \mathrm{nM}$ (Fig. 2A). Dex also dose-dependently decreased protein levels of astrocytic $\mathrm{ET}_{\mathrm{A}}$ and $\mathrm{ET}_{\mathrm{B}}$ receptors (Fig. 2B). Hydrocortisone (300 nM), an endogenous GC, decreased mRNA levels of astrocytic $\mathrm{ET}_{\mathrm{A}}$ and $\mathrm{ET}_{\mathrm{B}}$ receptors (Fig. 3A). Decreased ET receptor mRNA expressions by Dex and hydrocortisone were abolished by the addition of $50 \mathrm{nM}$ mifepristone, a GC receptor antagonist (Fig. 3, B and C).

Reduction of ET-Induced MMP Production by Pretreatment with Dex. MMPs are zinc endopeptidases that degenerate several extracellular matrix and membrane proteins on the cell surface. The excessive production of brain MMPs causes brain edema and infiltration of inflammatory cells through disruption of the BBB. Astrocytes produce MMP2, MMP3, and MMP9, whose functions are stimulated by ETs (Koyama and Tanaka, 2008, 2010). To clarify whether the Dex-induced downregulation of astrocytic ET receptors would affect astrocytic functions, the effect of Dex on MMP production by ET-1 was examined. Treatment of cultured

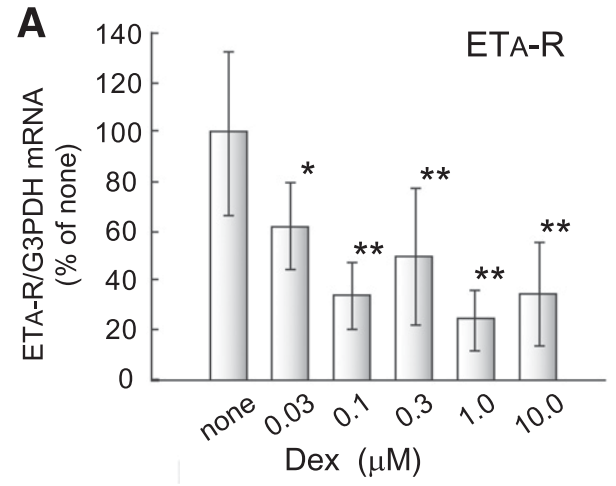

B
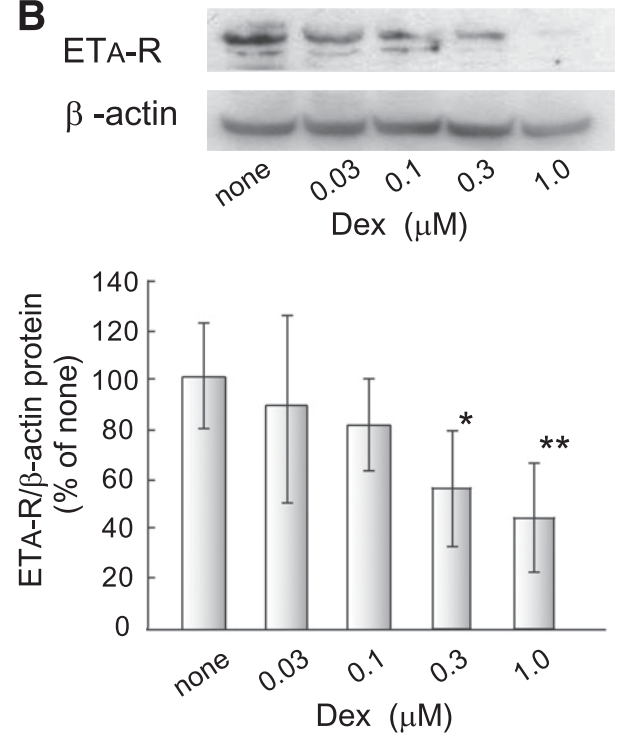
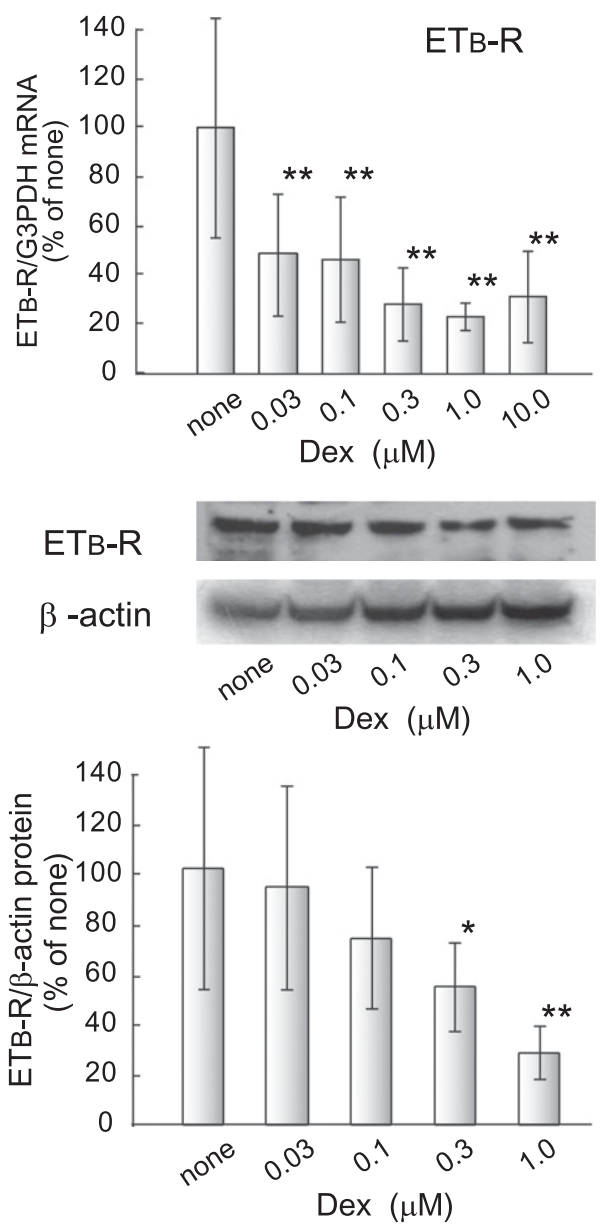

Fig. 2. (A) Dose responses of Dex-induced decreases in astrocytic ET receptor mRNAs. Cultured astrocytes were treated with the indicated concentrations of Dex for 24 hours. The results are the mean \pm SD of seven to eight experiments. $* P<0.05$ $* * P<0.01$ versus none by one-way ANOVA followed by Dunnett's test. (B) Dose responses of Dex-induced decreases in astrocytic ET receptor proteins. Cultured astrocytes were treated with the indicated concentrations of Dex for 24 hours. The results are the mean $\pm \mathrm{SD}$ of six to seven experiments. $* P<0.05, * * P<0.01$ versus none by one-way ANOVA followed by Dunnett's test. $\mathrm{ET}_{\mathrm{A}}-\mathrm{R}, \mathrm{ET}_{\mathrm{A}}$ receptor; $\mathrm{ET}_{\mathrm{B}}, \mathrm{ET}_{\mathrm{B}}$ receptor. 


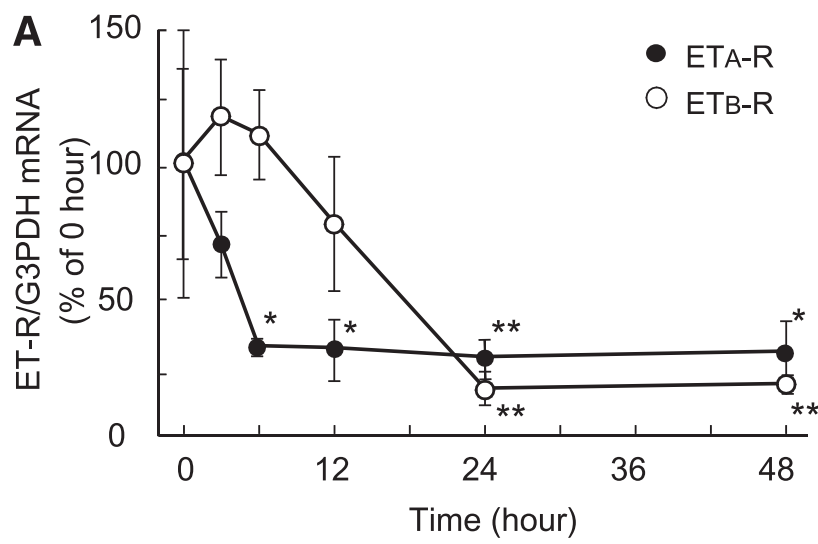

B
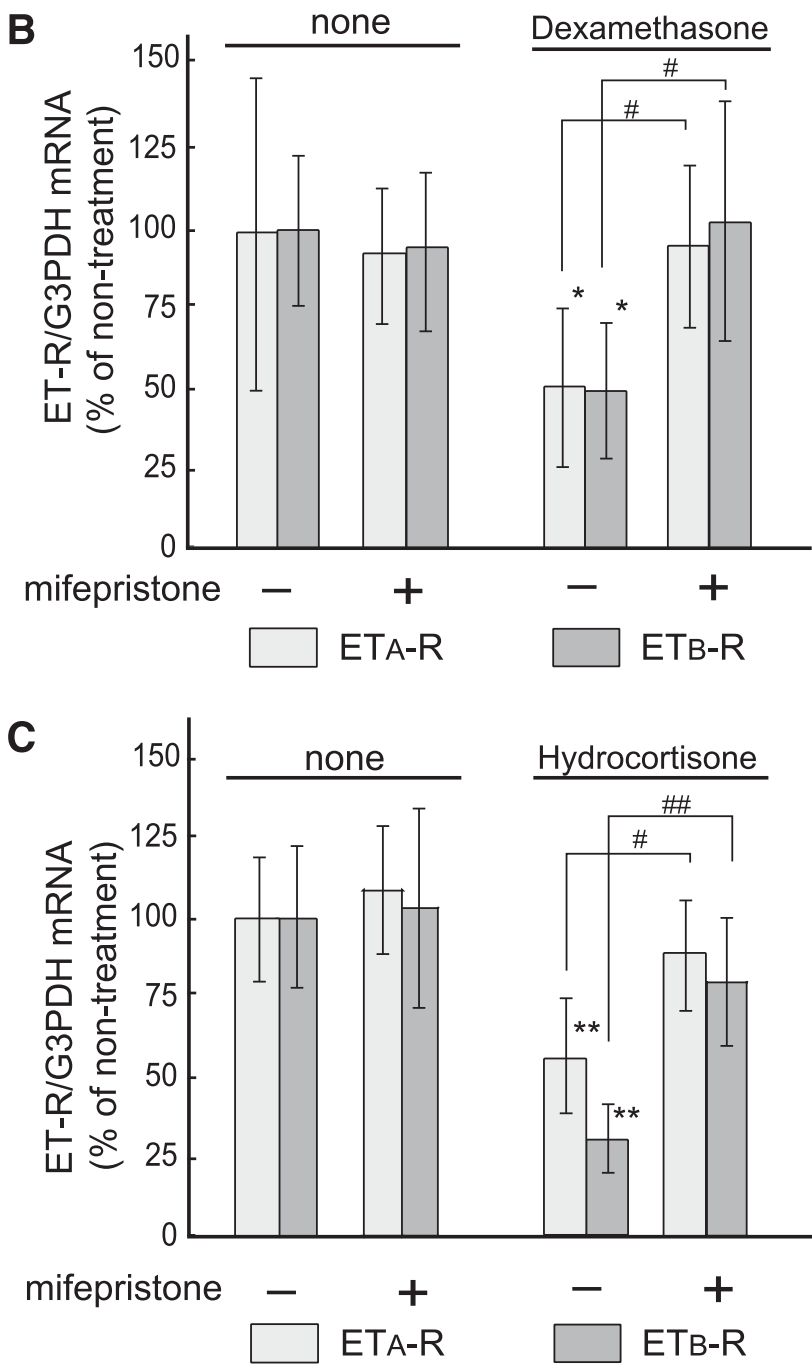

Fig. 3. (A) Effects of hydrocortisone on ET receptor mRNA expression. Cultured astrocytes were treated with $300 \mathrm{nM}$ hydrocortisone for the times indicated. The expression of ET receptor (ET-R) mRNAs was normalized to G3PDH. The results are expressed as the mean \pm SD of seven experiments. $* P<0.05, * * P<0.01$ versus 0 time by one-way ANOVA followed by Dunnett's test. (B) Effects of mifepristone on Dex-induced decreases in ET-R mRNAs. Cultured astrocytes were treated with $30 \mathrm{nM}$ Dex for 48 hours in the presence or absence of $50 \mathrm{nM}$ mifepristone. The results are expressed as the mean \pm SD of $13-14$ experiments. $* P<0.05$ versus nontreatment (no Dex in the absence of mifepristone); $\# P<0.05$ versus no mifepristone by two-way ANOVA followed by Tukey's test. (C) Effects of mifepristone on hydrocortisone-induced decreases in ET-R mRNAs. Cultured astrocytes were treated with $50 \mathrm{nM}$ hydrocortisone for 48 hours in the presence or absence of $50 \mathrm{nM}$ mifepristone. The results are
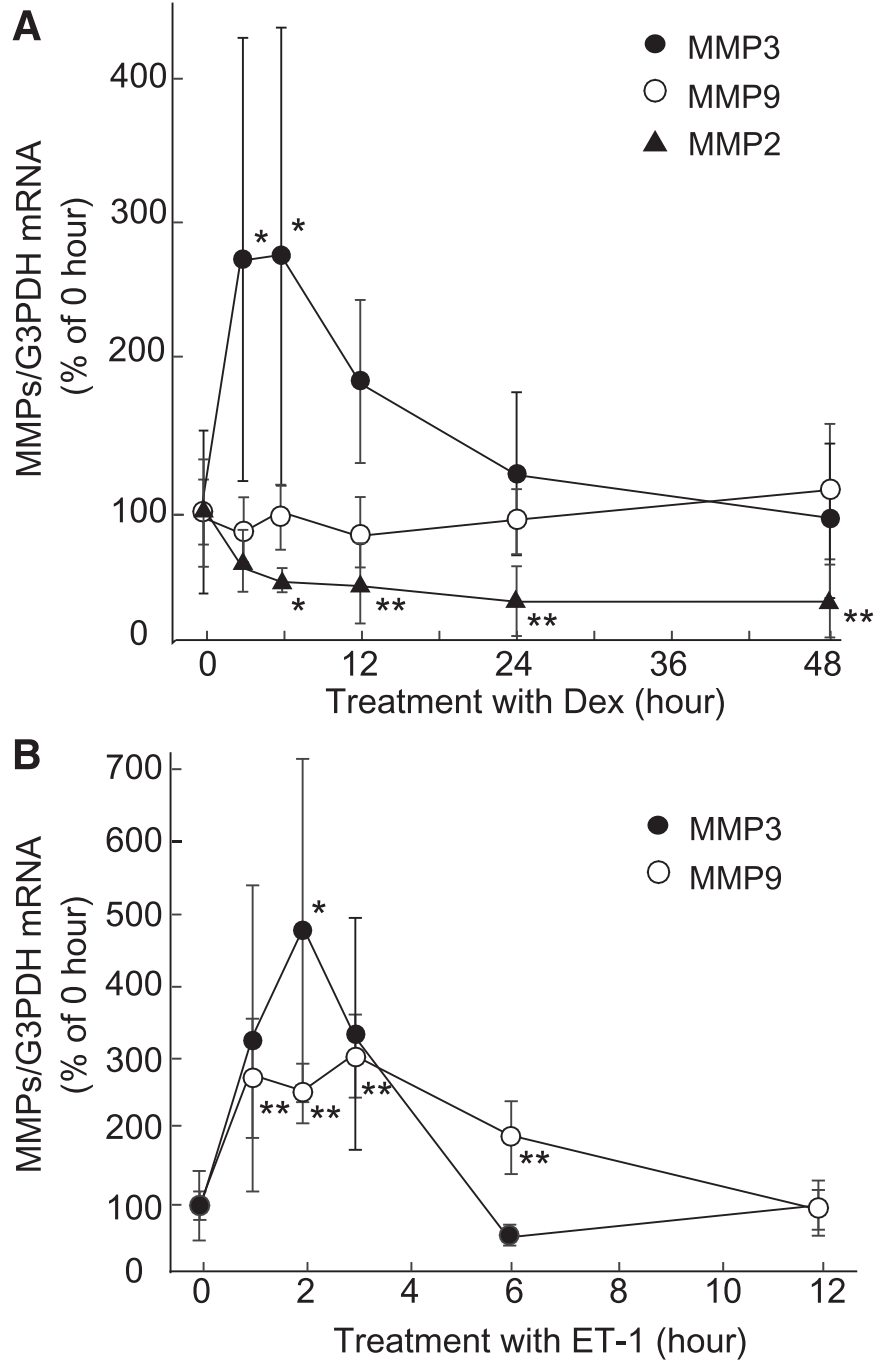

Fig. 4. (A) Effects of Dex on MMP3 and MMP9 mRNA expression in cultured rat astrocytes. Cultured astrocytes were treated with $300 \mathrm{nM}$ Dex for the times indicated. The expression of MMP3 (black circle) and MMP9 (white circle) mRNAs were normalized to that of G3PDH. The results are expressed as the mean $\pm \mathrm{SD}$ of $11-12$ experiments. ${ }^{*} P<0.05$ versus 0 time by one-way ANOVA followed by Dunnett's test. (B) Effects of ET-1 on MMP3 and MMP9 mRNA expression in cultured rat astrocytes. Cultured astrocytes were treated with $100 \mathrm{nM}$ ET- 1 for the times indicated. The expression of MMP3 (black circle) and MMP9 (white circle) mRNAs was normalized to that of G3PDH. The results are expressed as the mean \pm SD of $7-12$ experiments. $* P<0.05$, $* * P<0.01$ versus 0 time by one-way ANOVA followed by Dunnett's test.

astrocytes with $300 \mathrm{nM}$ Dex for $3-48$ hours did not decrease MMP3 mRNA expression, but transient increases were observed after 3-6 hours of treatment (Fig. 4A). MMP9 mRNA expression was not altered by Dex treatment for 3-48 hours, whereas MMP2 mRNA expression was decreased.

ET-1 (100 nM) increased astrocytic MMP3 and MMP9 mRNA expression (Fig. 4B). Two-way ANOVA showed statistically significant effects of interactions between ET-1 and Dex treatments on MMP3 and MMP9 mRNA expression (MMP3:

expressed as the mean $\pm \mathrm{SD}$ of $11-12$ experiments. $* * P<0.01$ versus nontreatment; $\# P<0.05$, \#\#P $<0.01$ versus no mifepristone by two-way ANOVA followed by Tukey's test. $\mathrm{ET}_{\mathrm{A}}-\mathrm{R}, \mathrm{ET}_{\mathrm{A}}$ receptor; $\mathrm{ET}_{\mathrm{B}}, \mathrm{ET}_{\mathrm{B}}$ receptor. 

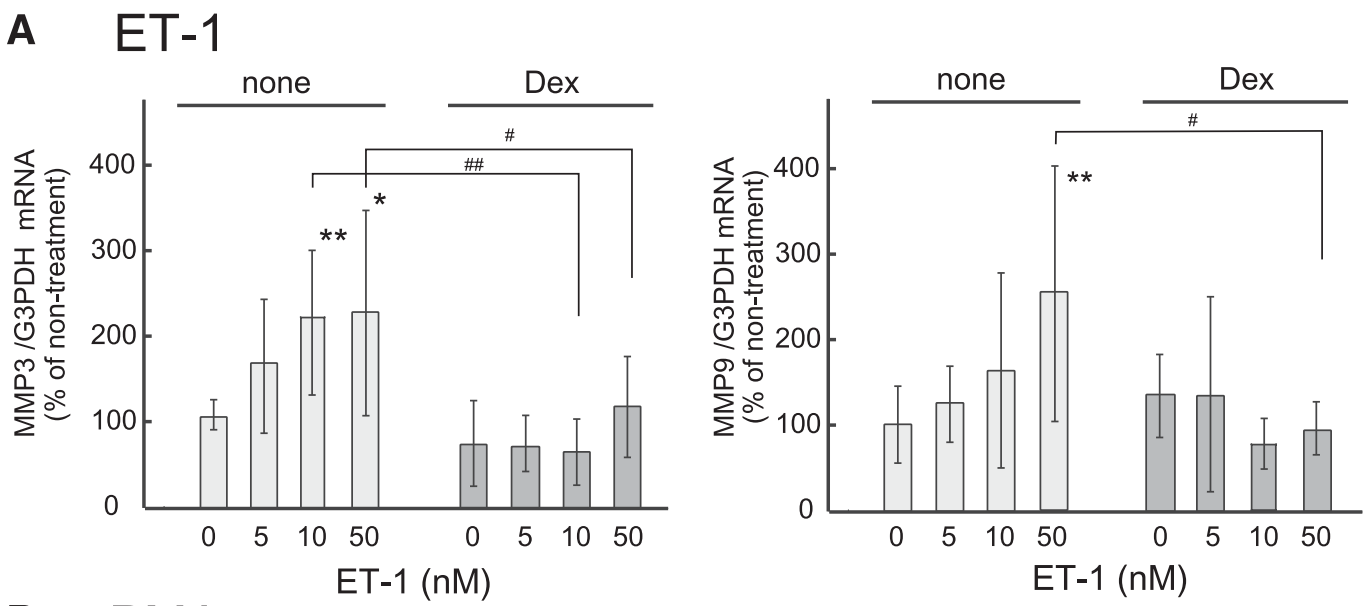

\section{B PMA}
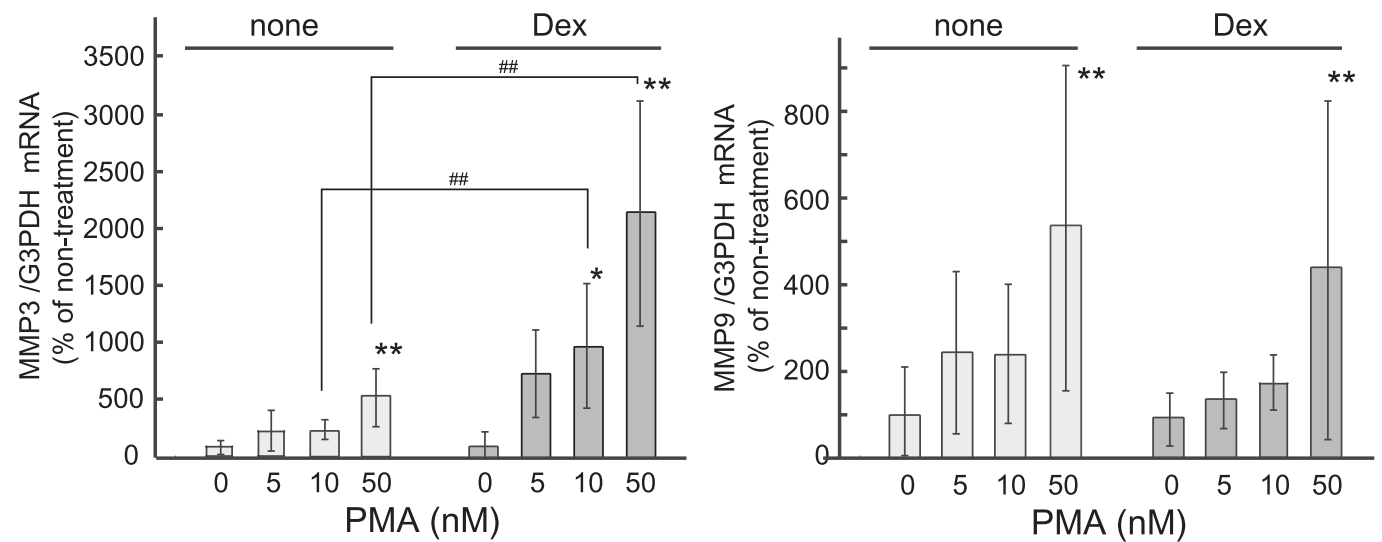

Fig. 5. Effects of pretreatment with Dex on ET- or PMA-induced increases in MMP mRNAs. (A) ET-1. Cultured astrocytes were treated with 300 nM Dex for 48 hours in serum-free MEM. After the pretreatment, fresh serum-free MEM replaced the Dex-containing MEM, and astrocytes were further incubated for 3 hours. Then, astrocytes were treated with ET-1 for 2 hours at the concentrations indicated. MMP3 and MMP9 mRNA expressions were determined as described above. The results are the mean \pm SD of 6 and 10 experiments for MMP3 and MMP9, respectively. $* P<0.05$, **P $P<0.01$ versus $0 \mathrm{nM}$ ET-1; $\# P<0.05$, \#\#P<0.01 versus no Dex pretreatment by two-way ANOVA followed by Fisher's test. (B) PMA. Cultured astrocytes were treated with Dex as described above. Then, cultured astrocytes were treated with PMA for 6 hours at the concentrations indicated, and the expression of MMP3 and MMP9 mRNAs were determined. The results are the mean \pm SD of seven and nine experiments for MMP3 and MMP9, respectively. ${ }^{*} P<0.05, * * P<$ 0.01 versus 0 nM PMA; \#P $<0.05$, \#\#P $<0.01$ versus no Dex pretreatment by two-way ANOVA followed by Fisher's test.

$F(1,3)=5.419, P<0.05$, MMP9: $F(1,3)=5.086, P<0.05)$, where the effects of ET-1 were attenuated (Fig. 5A). ETs stimulated astrocytic MMP3 and MMP9 production through the activation of protein kinase $\mathrm{C}$ (PKC) (Koyama and Tanaka, 2008, 2010). PMA (100 nM), a PKC activator, increased MMP3 and MMP9 mRNA expression in cultured astrocytes (Fig. 5B). Pretreatment with Dex showed no interaction with an effect of PMA on MMP9 expression $(F(1,3)=0.148, P=0.930$, by twoway ANOVA). On the other hand, a statistically significant interaction between Dex and PMA treatments was shown in MMP3 expression $(F(1,3)=9.284, P<0.001$, by two-way ANOVA) (Fig. 5B), where the effect of PMA was enhanced but not attenuated (Fig. 5B). ET-1 increased the release of MMP3 and MMP9 proteins from cultured astrocytes (Fig. 6). The ET-induced release of MMP3 and MMP9 proteins was reduced by pretreatment with Dex.

Reduction of ET-Induced ERK1/2 Activation by Pretreatment with Dex. Stimulation of astrocytic ET receptors induces the activation of ERK1/2, which involves astrocytic MMP3 and MMP9 production (Koyama and Tanaka, 2008, 2010). The effects of pretreatment with Dex on ET-induced ERK1/2 activation were examined. ET-1 (100 nM) increased the phosphorylated (activated) forms of ERK1/2 proteins in cultured astrocytes (Fig. 7A). Pretreatment with $300 \mathrm{nM}$ Dex had no effect on the basal levels of astrocytic ERK1/2 phosphorylation. However, two-way ANOVA showed a statistically significant effect of interaction between ET-1 and Dex treatments on ERK1/2 phosphorylation $(F(1,3)=4.174, P<$ 0.05) (Fig. 7A). In contrast, pretreatment with Dex showed no interaction with effect of PMA on ERK1/2 phosphorylation in cultured astrocytes $(F(1,3)=0.682, P=0.563)$ (Fig. 7B).

\section{Discussion}

Dex Downregulates $\mathbf{E T}_{\mathrm{A}}$ and $\mathrm{ET}_{\mathrm{B}}$ Receptors in Cultured Rat Astrocytes. In brain disorders, reactive astrocytes produce and release soluble factors to increase the permeability of brain microvessels, which causes brain edema and allows the infiltration of inflammatory cells (Lopes Pinheiro et al., 2016; Stokum et al., 2016). Therefore, the management of astrocytic activation might be a promising target for novel neuroprotective drugs (Buffo et al., 2010; Karimi-Abdolrezaee and Billakanti, 2012). The activation of ET signaling promotes the phenotypic conversion of normal 


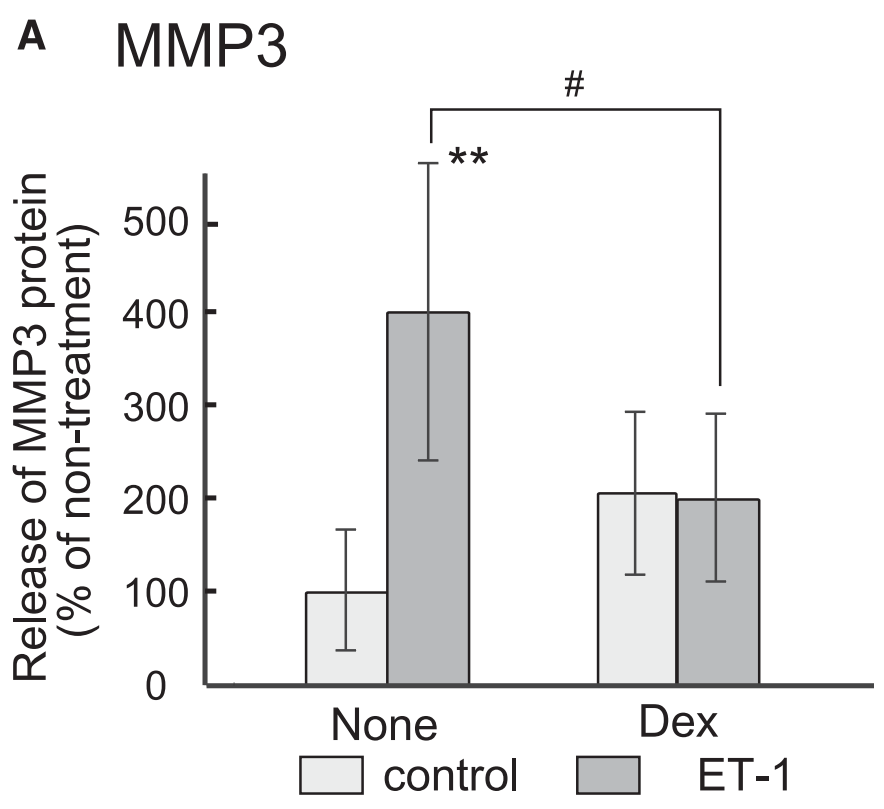

\section{B $\quad$ MMP9}

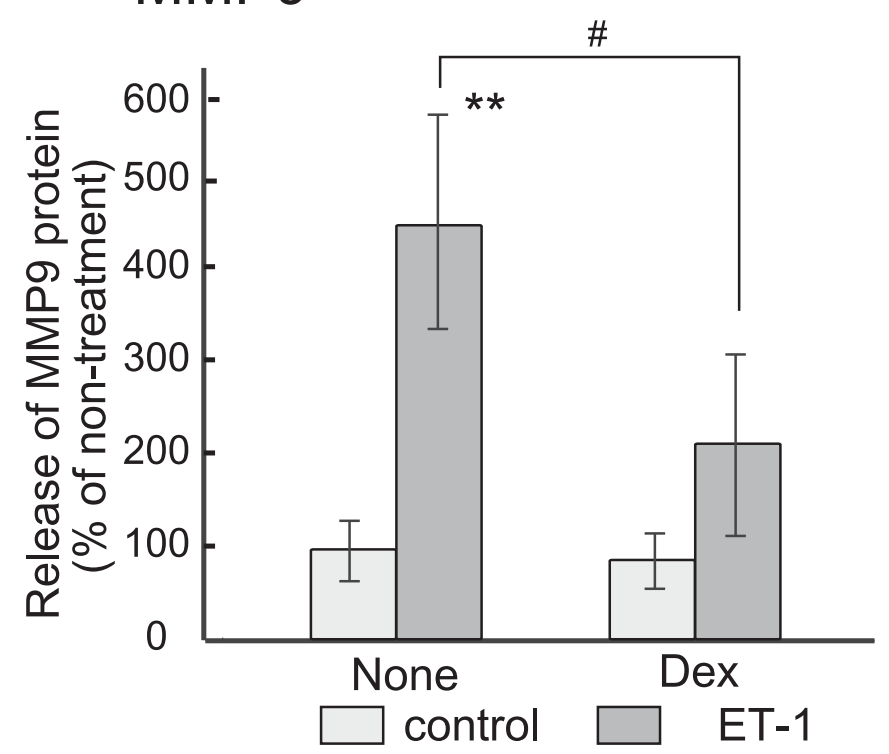

Fig. 6. Effects of pretreatment with Dex on ET-induced release of MMP3 and MMP9 proteins from cultured astrocytes. Cultured astrocytes were treated with $300 \mathrm{nM}$ Dex for 48 hours in serum-free MEM. After Dex pretreatment, fresh serum-free MEM replaced the Dex-containing MEM, and the astrocytes were further incubated for 3 hours. Then astrocytes were further cultured in the presence or absence of $100 \mathrm{nM}$ ET-1 for 12 hours. Concentrations of MMP3 (A) and MMP9 (B) proteins in cultured medium were determined by enzyme-linked immunosorbent assay. The results are the mean $\pm \mathrm{SD}$ of eight experiments and are expressed as a percentage of the control with no Dex treatment. The results are the mean $\pm \mathrm{SD}$ of six experiments. $* * P<0.01$ versus control; $\# P<0.05$ versus no Dex treatment by two-way ANOVA followed by Tukey's test.

astrocytes to reactive astrocytes and the production of vascular permeability factors (Koyama and Tanaka, 2008, 2010; Koyama et al., 2011, 2012, 2013). In contrast, the administration of GCs, such as Dex, reduces the induction of reactive astrocytes accompanied by an amelioration of brain edema and neuroinflammation (Holmin and Mathiesen, 1996; Genovese et al., 2007; Yang et al., 2011; Lee et al., 2015). However, interactions between GC and ET signals in astrocytes have not been reported. In this study, treatment with Dex and hydrocortisone decreased the expressions of $\mathrm{ET}_{\mathrm{A}}$ and $\mathrm{ET}_{\mathrm{B}}$ receptors in cultured rat astrocytes (Figs. 1-3). The effects of Dex and hydrocortisone were antagonized by mifepristone (Fig. 3, B and C), suggesting the involvement of nuclear GC receptors. Both $\mathrm{ET}_{\mathrm{A}}$ and $\mathrm{ET}_{\mathrm{B}}$ receptors, which are G-protein-coupled receptors and linked to $\mathrm{Gq}$ subtypes, are present in the brain. However, these ET receptors are differently expressed among brain cells. Previous studies showed that $\mathrm{ET}_{\mathrm{B}}$ types were highly expressed in astrocytes (Peters et al., 2003; Rogers et al., 2003; Wilhelmsson et al., 2004). The higher expression of $\mathrm{ET}_{\mathrm{B}}$ receptors compared with $\mathrm{ET}_{\mathrm{A}}$ receptors by astrocytes was confirmed by comparing their mRNA copy numbers (Table 1). The administration of an $\mathrm{ET}_{\mathrm{B}^{-}}$ selective agonist promoted the induction of GFAP-positive reactive astrocytes in rat brain (Ishikawa et al., 1997; Koyama et al., 2003), whereas $\mathrm{ET}_{\mathrm{B}}$ antagonists, but not $\mathrm{ET}_{\mathrm{A}}$ antagonists, decreased reactive astrocytes in the injured brain (Koyama et al., 1999; Michinaga et al., 2014, 2015). These findings suggest that $\mathrm{ET}_{\mathrm{B}}$ receptors are predominantly involved in the ET-induced phenotypic conversion to reactive astrocytes. In contrast to the actions of ETs, Dex inhibited the induction of GFAP-positive reactive astrocytes and their functions (Imai et al., 2001; Spataro et al., 2005; Unemura et al., 2012). As for GFAP expression, we found that treatments with Dex had no effect on GFAP mRNA levels in cultured astrocytes by themselves (Supplemental Fig. 1). Therefore, the downregulation of astrocytic ET receptors, especially $\mathrm{ET}_{\mathrm{B}}$, by Dex might be related to the inhibitory actions of Dex on astrocytic phonotypic conversion.

Shibata et al. (1995) reported that the administration of Dex decreased $\mathrm{ET}_{\mathrm{B}}$ receptor expression in the rat hypothalamus, although the cell types showing ET receptor downregulation were not examined. In this report, the authors suggested that the increased production of brain ET-1 by Dex indirectly caused the decrease in $\mathrm{ET}_{\mathrm{B}}$ receptors. Supporting this mechanism, the production of ET-1 in cultured astrocytes was increased by a high concentration $(10 \mu \mathrm{M})$ of Dex (Hasselblatt et al., 2001). However, the Dex-induced production of ET-1 is unlikely to mediate the effects of Dex, because the concentrations of Dex used in the present study (300 nM) did not increase preproET-1 mRNA levels in cultured astrocytes (Fig. 1A). In addition, we confirmed that treatment with $300 \mathrm{nM}$ Dex for 6-24 hours did not stimulate the extracellular release of ET-1 peptide from cultured astrocytes (Supplemental Fig. 2 ). Therefore, mechanisms other than ET receptor activation are thought to underlie the Dex-induced downregulation of astrocytic ET receptors.

Dex Reduced ET-Induced Production of MMP3 and MMP9. MMPs are endopeptidases that regulate tissue remodeling by degenerating extracellular matrix proteins. In brain disorders, the production of MMP2, MMP3, and MMP9 are increased, causing brain edema and the infiltration of inflammatory cells by disrupting the BBB (Planas et al., 2001; Rosell and Lo, 2008). Astrocytes produce MMP2, MMP3, and MMP9, which are stimulated with their conversion to reactive astrocytes (Muir et al., 2002; Rivera et al., 2002; Koyama and Tanaka, 2010). The administration of Dex decreased MMP3 and MMP9 production induced by brain injury and cytokines in nerve tissue and glial cells (Liu et al., 2008; Tenenbaum et al., 2008; Green et al., 2010; Yang et al., 2011). We found that treatment with Dex did not decrease basal levels of 
A ET-1

phospho-ERK

total ERK
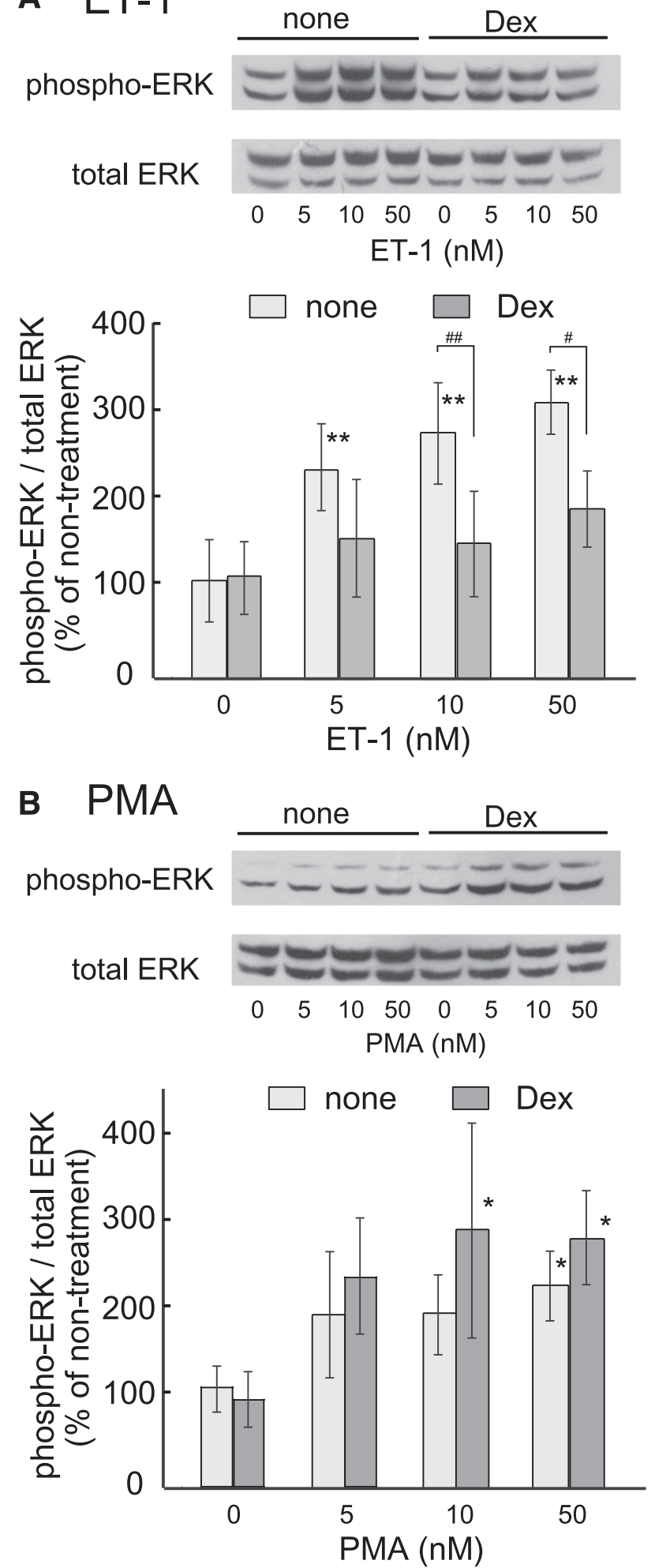

Fig. 7. Effects of pretreatment with Dex on the phosphorylation of ERK1/2 by ET-1 and PMA. (A) ET-1. Cultured astrocytes were treated with $300 \mathrm{nM}$ Dex for 48 hours in serum-free MEM. After Dex pretreatment, fresh serum-free MEM replaced the Dex-containing MEM, and the astrocytes were further incubated for 3 hours. Then, astrocytes were treated with ET-1 for 20 minutes at the concentrations indicated. Phosphorylated and total ERK1/2 proteins were detected by immunoblotting and quantified. Phosphorylation of ERK1/2 is presented as the ratio of phosphorylated proteins to total proteins. The results are the mean $\pm \mathrm{SD}$ of seven experiments. ${ }^{*} * P<0.01$ versus respective $0 \mathrm{nM}$ ET- 1 ; \#P<0.05, $\# \# P<0.01$ versus no Dex treatment by two-way ANOVA followed by
MMP3 and MMP9 expression in cultured astrocytes (Fig. 4A). However, pretreatment with Dex reduced the effects of ET-1 on MMP3 and MMP9 production (Fig. 5A). These results suggest that Dex attenuated ET receptor-mediated signals, leading to MMP3 and MMP9 production. The activation of PKC and ERK signaling are involved in astrocytic MMP3 and MMP9 production (Arai et al., 2003; Lee et al., 2003; Kunapuli et al., 2004). In agreement with these observations, PMA activated astrocytic ERK1/2 and stimulated MMP expression (Fig. 5B; Fig. 7B), and ET-induced astrocytic MMP3 and MMP9 production was mediated by PKC/ERK signals (Koyama and Tanaka, 2008, 2010). Although both ET-1 and PMA activated ERK1/2, different effects of Dex on ERK1/2 activation were obtained (Fig. 7). Dex reduced the activation of ERK1/2 by ET-1 but not by PMA. In addition, the inhibitory actions of Dex on MMP production were shown during ET-1, but not PMA, treatment (Fig. 5). These findings suggest that Dex attenuates ET signals leading to astrocytic MMP production upstream of PKC/ERK activation. Treatment with Dex decreased the expression of astrocytic $\mathrm{ET}_{\mathrm{A}}$ and $\mathrm{ET}_{\mathrm{B}}$ receptors (Fig. 1; Fig. 2). Considering the effects of Dex on ET receptors, the selective reduction of ET signals might be caused by the downregulation of ET receptors. Because the stimulation of either $\mathrm{ET}_{\mathrm{A}}$ or $\mathrm{ET}_{\mathrm{B}}$ receptors activated PKC/ERK signals through Gq protein (Koyama, 2013), both ET receptor types are involved in ET-induced MMP production. However, the levels of $\mathrm{ET}_{\mathrm{B}}$ receptors in cultured astrocytes were much higher than those of $\mathrm{ET}_{\mathrm{A}}$ receptors (Table 1). Moreover, ET-induced astrocytic MMP3 and MMP9 production was selectively inhibited by an $\mathrm{ET}_{\mathrm{B}}$ antagonist but not by an $\mathrm{ET}_{\mathrm{A}}$ antagonist (Koyama and Tanaka, 2008, 2010). Thus, although an involvement of $\mathrm{ET}_{\mathrm{A}}$ receptors cannot be excluded, the major effect of Dex on ET-induced MMP3 and MMP9 productions is mediated by the downregulation of $\mathrm{ET}_{\mathrm{B}}$ receptors. Differing from MMP3 and MMP9, astrocytic MMP2 was decreased by Dex treatment (Fig. 4A). MMP2 cleaves an inactive form of MMP9 to activate it. So, in addition to the actions on ET receptors, Dex may decrease MMP9 activity also by the reduction of astrocytic MMP2 production.

Although prolonged treatments with Dex attenuated the effects of ET-1 on MMP3 expression, a transient increase in MMP3 mRNA expression was also observed (Fig. 4B). In addition, pretreatment with Dex enhanced PMA-induced MMP3 expression (Fig. 5B). These observations suggest a stimulatory action of Dex on astrocytic MMP3 production. The transient increase in MMP3 mRNA levels was not reduced by mifepristone (Supplemental Fig. 3). Pretreatment with Dex did not affect PMA-induced ERK activation (Fig. 7B). These observations indicate that the activation of either PKC/ERK or nuclear GC receptor does not mediate the stimulatory action on MMP3 production by Dex. Because stimulatory actions of Dex and other GCs on MMP3 production have not been reported in any cell types, at present, we cannot refer to

Tukey's test. (B) PMA. Cultured astrocytes were treated with $300 \mathrm{nM}$ Dex for 48 hours in serum-free MEM. After Dex pretreatment, fresh serum-free MEM replaced the Dex-containing MEM, and the astrocytes were further incubated for 3 hours. Then, astrocytes were treated with PMA for 20 minutes at the concentrations indicated. The results are the mean \pm SD of six experiments. ${ }^{*} P<0.05, * * P<0.01$ versus respective $0 \mathrm{nM}$ PMA by two-way ANOVA followed by Tukey's test. 
possible mechanisms clearly. However, in hippocampal neurons, treatments with Dex caused an increase in cytosolic $\mathrm{Ca}^{2+}$ and enhanced neurotoxicity through mifepristoneinsensitive and nongenomic mechanisms (Takahashi et al., 2002; Xiao et al., 2010). As for the nongenomic actions of Dex, an involvement of membrane-bound GC receptors, which have not been identified yet, was suggested (Groeneweg et al., 2012). So, it may be possible that the stimulatory action on MMP3 expression is mediated by membrane-bound GC receptors and is related to the neurotoxicity of Dex.

Significance of Dex-Induced Downregulation of Astrocytic ET Receptors; a Mechanism of Anti-Brain Edema Action. Brain edema is a mortal pathologic state that occurs during the acute phase of stroke and head trauma, and the management of brain edema is critical to improve the prognosis of patients. GCs, such as Dex, were shown to prevent disruption of the $\mathrm{BBB}$ and brain edema formation in animal models of intracerebral hemorrhage (Yang et al., 2011; Lee et al., 2015), nerve trauma (Holmin and Mathiesen, 1996; Genovese et al., 2007), and brain tumor (Gu et al., 2009; Fan et al., 2014). However, the mechanisms underlying the neuroprotective actions of GCs have not been fully determined. Investigations on the anti-brain edema action of GCs have proposed several mechanisms, including inhibitory actions on proinflammatory cells and the stabilization of tight junctions in brain endothelial cells (Salvador et al., 2014). In addition, astrocytes are thought to be involved in the actions of GCs because their conversion to reactive astrocytes was inhibited by GCs (Imai et al., 2001; Spataro et al., 2005; Unemura et al., 2012). In perivascular areas, astrocytes surround brain microvessels with a specialized structure called "end-feet." The astrocyte-endothelial cell unit has a major role in BBB functions (Wolburg et al., 2009; Alvarez et al., 2013), where barrier functions of the BBB are dynamically controlled by astrocyte-derived permeability factors. The production of astrocyte-derived permeability factors are stimulated by the conversion to reactive astrocytes (Buffo et al., 2010; Burda et al., 2016), and this disrupts the BBB, leading to brain edema and the infiltration of inflammatory cells (Lopes Pinheiro et al., 2016; Stokum et al., 2016). In injured nerve tissues, reactive astrocytes produce MMP3 and MMP9 (Muir et al., 2002; Rivera et al., 2002; Koyama and Tanaka, 2010), which increase vascular permeability by degrading the basal lamina and endothelial tight junctions (Planas et al., 2001; Rosell and Lo, 2008). The administration of an $\mathrm{ET}_{\mathrm{B}}$ antagonist prevented the induction of reactive astrocytes after brain injury (Koyama et al., 1999; Kim et al., 2013). Moldes et al. (2012) showed that ET antagonists alleviated brain infarct and edema in a brain ischemia model. Our studies on brain edema formation and BBB disruption after cold injury to the brain showed that the protective actions of ET antagonists were mediated by a reduction of astrocytic permeability factors, including MMPs (Michinaga et al., 2015). These studies indicate that a reduction of astrocytic ET signals is beneficial to prevent brain edema formation and BBB disruption. The present study showed that Dex downregulated ET receptors and attenuated ET signals in astrocytes. The administration of GCs is known to have beneficial effects against disruption of the BBB, brain edema, and neuroinflammation in several brain disorders (Kim et al., 2008; Salvador et al., 2014). Although further examinations by using in vivo brain injury models are required, the
Dex-induced downregulation of astrocytic ET receptors may be involved in the neuroprotective actions of GCs.

\section{Authorship Contribution}

Participated in research design: Koyama and Tokuyama. Conducted experiments: Koyama, Ukita, Abe, Iwamae, and Kotake. Performed data analysis: Tanaka and Kotake

Wrote or contributed to the writing of the manuscript: Koyama.

\section{References}

Alvarez JI, Katayama T, and Prat A (2013) Glial influence on the blood brain barrier. Glia 61:1939-1958.

Arai K, Lee SR, and Lo EH (2003) Essential role for ERK mitogen-activated protein kinase in matrix metalloproteinase-9 regulation in rat cortical astrocytes. Glia 43: 254-264

Bracken MB, Shepard MJ, Collins WF, Holford TR, Young W, Baskin DS, Eisenberg HM, Flamm E, Leo-Summers L, Maroon J, et al. (1990) A randomized, controlled trial of methylprednisolone or naloxone in the treatment of acute spinal-cord injury. Results of the Second National Acute Spinal Cord Injury Study. N Engl J Med 322:1405-1411.

Bracken MB, Shepard MJ, Holford TR, Leo-Summers L, Aldrich EF, Fazl M, Fehlings M, Herr DL, Hitchon PW, Marshall LF, et al. (1997) Administration of methylprednisolone for 24 or 48 hours or tirilazad mesylate for 48 hours in the treatment of acute spinal cord injury. Results of the Third National Acute Spinal Cord Injury Randomized Controlled Trial. National Acute Spinal Cord Injury Study. JAMA 277:1597-1604.

Buffo A, Rolando C, and Ceruti S (2010) Astrocytes in the damaged brain: molecular and cellular insights into their reactive response and healing potential. Biochem Pharmacol 79:77-89.

Burda JE, Bernstein AM, and Sofroniew MV (2016) Astrocyte roles in traumatic brain injury. Exp Neurol 275:305-315.

Fan Z, Sehm T, Rauh M, Buchfelder M, Eyupoglu IY, and Savaskan NE (2014) Dexamethasone alleviates tumor-associated brain damage and angiogenesis. PLoS One 9:e93264.

Gadea A, Schinelli S, and Gallo V (2008) Endothelin-1 regulates astrocyte proliferation and reactive gliosis via a JNK/c-Jun signaling pathway. $J$ Neurosci 28 : $2394-2408$

Genovese T, Mazzon E, Crisafulli C, Esposito E, Di Paola R, Muià C, Di Bella P, Mel R, Bramanti P, and Cuzzocrea S (2007) Combination of dexamethasone and etanercept reduces secondary damage in experimental spinal cord trauma. Neuroscience 150:168-181.

Green JA, Elkington PT, Pennington CJ, Roncaroli F, Dholakia S, Moores RC, Bullen A, Porter JC, Agranoff D, Edwards DR, et al. (2010) Mycobacterium tuberculosis upregulates microglial matrix metalloproteinase-1 and -3 expression and secretion via NF-kappaB- and Activator Protein-1-dependent monocyte networks. J Immunol 184:6492-6503.

Groeneweg FL, Karst H, de Kloet ER, and Joëls M (2012) Mineralocorticoid and glucocorticoid receptors at the neuronal membrane, regulators of nongenomic corticosteroid signalling. Mol Cell Endocrinol 350:299-309.

Gu YT, Qin LJ, Qin X, and Xu F (2009) The molecular mechanism of dexamethasonemediated effect on the blood-brain tumor barrier permeability in a rat brain tumor model. Neurosci Lett 452:114-118.

Hasselblatt M, Lewczuk P, Löffler BM, Kamrowski-Kruck H, von Ahsen N, Sirén AL, and Ehrenreich $\mathrm{H}$ (2001) Role of the astrocytic $\mathrm{ET}_{\mathrm{B}}$ receptor in the regulation of extracellular endothelin-1 during hypoxia. Glia 34:18-26.

Holmin S and Mathiesen T (1996) Dexamethasone and colchicine reduce inflammation and delayed oedema following experimental brain contusion. Acta Neurochir (Wien) 138:418-424.

Hwang IK, Yoo KY, Nam YS, Choi JH, Lee IS, Kwon YG, Kang TC, Kim YS, and Won MH (2006) Mineralocorticoid and glucocorticoid receptor expressions in astrocytes and microglia in the gerbil hippocampal CA1 region after ischemic insult. Neurosci Res 54:319-327.

Imai H, Nishimura T, Sadamatsu M, Liu Y, Kabuto M, and Kato N (2001) Type II glucocorticoid receptors are involved in neuronal death and astrocyte activation induced by trimethyltin in the rat hippocampus. Exp Neurol 171:22-28.

Ishikawa N, Takemura M, Koyama Y, Shigenaga Y, Okada T, and Baba A (1997) Endothelins promote the activation of astrocytes in rat neostriatum through $\mathrm{ET}_{\mathrm{B}}$ receptors. Eur $J$ Neurosci 9:895-901.

Karimi-Abdolrezaee S and Billakanti R (2012) Reactive astrogliosis after spinal cord injury-beneficial and detrimental effects. Mol Neurobiol 46:251-264.

Kim H, Lee JM, Park JS, Jo SA, Kim YO, Kim CW, and Jo I (2008) Dexamethasone coordinately regulates angiopoietin-1 and VEGF: a mechanism of glucocorticoidinduced stabilization of blood-brain barrier. Biochem Biophys Res Commun 372: 243-248.

Kim JE, Ryu HJ, and Kang TC (2013) Status epilepticus induces vasogenic edema via tumor necrosis factor- $\alpha /$ endothelin-1-mediated two different pathways. PLoS One 8:e74458

Koyama Y (2013) Endothelin systems in the brain: involvement in pathophysiological responses of damaged nerve tissues. Biomol Concepts 4:335-347.

Koyama Y (2014) Signaling molecules regulating phenotypic conversions of astrocytes and glial scar formation in damaged nerve tissues. Neurochem Int 78:35-42

Koyama Y and Tanaka K (2008) Endothelins stimulate the production of stromelysin1 in cultured rat astrocytes. Biochem Biophys Res Commun 371:659-663.

Koyama Y and Tanaka K (2010) Intracerebroventricular administration of an endothelin $\mathrm{ET}_{\mathrm{B}}$-receptor agonist increases expression of matrix metalloproteinase2 and -9 in rat brain. J Pharmacol Sci 114:433-443. 
Koyama Y and Michinaga S (2012) Regulations of astrocytic functions by endothelins: roles in the pathophysiological responses of damaged brains. J Pharmacol Sci 118: 401-407.

Koyama Y, Takemura M, Fujiki K, Ishikawa N, Shigenaga Y, and Baba A (1999) $\mathrm{BQ788}$, an endothelin $\mathrm{ET}_{\mathrm{B}}$ receptor antagonist, attenuates stab wound injuryinduced reactive astrocytes in rat brain. Glia 26:268-271.

Koyama Y, Tsujikawa K, Matsuda T, and Baba A (2003) Intracerebroventricular administration of an endothelin $\mathrm{ET}_{\mathrm{B}}$ receptor agonist increases expressions of GDNF and BDNF in rat brain. Eur $J$ Neurosci 18:887-894

Koyama Y, Nagae R, Tokuyama S, and Tanaka K (2011) I.c.v administration of an endothelin $\mathrm{ET}_{\mathrm{B}}$ receptor agonist stimulates vascular endothelial growth factor-A production and activates vascular endothelial growth factor receptors in rat brain. Neuroscience 192:689-698.

Koyama Y, Maebara Y, Hayashi M, Nagae R, Tokuyama S, and Michinaga S (2012) Endothelins reciprocally regulate VEGF-A and angiopoietin-1 production in cultured rat astrocytes: implications on astrocytic proliferation. Glia 60:1954-1963.

Koyama Y, Kotani M, Sawamura T, Kuribayashi M, Konishi R, and Michinaga S (2013) Different actions of endothelin-1 on chemokine production in rat cultured astrocytes: reduction of CX3CL1/fractalkine and an increase in CCL2/MCP-1 and CXCL1/CINC-1. J Neuroinflammation 10:51.

Kunapuli P, Kasyapa CS, Hawthorn L, and Cowell JK (2004) LGI1, a putative tumor metastasis suppressor gene, controls in vitro invasiveness and expression of matrix metalloproteinases in glioma cells through the ERK1/2 pathway. J Biol Chem 279: 23151-23157.

Lee WJ, Shin CY, Yoo BK, Ryu JR, Choi EY, Cheong JH, Ryu JH, and Ko KH (2003) Induction of matrix metalloproteinase-9 (MMP-9) in lipopolysaccharide-stimulated primary astrocytes is mediated by extracellular signal-regulated protein kinase $1 / 2$ (Erk1/2). Glia 41:15-24.

Lee IN, Cheng WC, Chung CY, Lee MH, Lin MH, Kuo CH, Weng HH, and Yang JT (2015) Dexamethasone reduces brain cell apoptosis and inhibits inflammatory response in rats with intracerebral hemorrhage. $J$ Neurosci Res 93:178-188.

Liu X, Han Q, Sun R, and Li Z (2008) Dexamethasone regulation of matrix metalloproteinase expression in experimental pneumococcal meningitis. Brain Res 1207: 237-243.

Lopes Pinheiro MA, Kooij G, Mizee MR, Kamermans A, Enzmann G, Lyck R, Schwaninger M, Engelhardt B, and de Vries HE (2016) Immune cell trafficking across the barriers of the central nervous system in multiple sclerosis and stroke. Biochim Biophys Acta 1862:461-471.

Michinaga S, Nagase M, Matsuyama E, Yamanaka D, Seno N, Fuka M, Yamamoto Y, and Koyama Y (2014) Amelioration of cold injury-induced cortical brain edema formation by selective endothelin $\mathrm{ET}_{\mathrm{B}}$ receptor antagonists in mice. PLoS One $\mathbf{9}$ e102009.

Michinaga S, Seno N, Fuka M, Yamamoto Y, Minami S, Kimura A, Hatanaka S, Nagase M, Matsuyama E, Yamanaka D, et al. (2015) Improvement of cold injuryinduced mouse brain edema by endothelin $\mathrm{ET}_{\mathrm{B}}$ antagonists is accompanied by decreases in matrixmetalloproteinase 9 and vascular endothelial growth factor-A. Eur J Neurosci 42:2356-2370.

Moldes O, Sobrino T, Blanco M, Agulla J, Barral D, Ramos-Cabrer P, and Castillo J (2012) Neuroprotection afforded by antagonists of endothelin-1 receptors in experimental stroke. Neuropharmacology 63:1279-1285.

Muir EM, Adcock KH, Morgenstern DA, Clayton R, von Stillfried N, Rhodes K, Ellis C, Fawcett JW, and Rogers JH (2002) Matrix metalloproteases and their inhibitors are produced by overlapping populations of activated astrocytes. Brain Res Mol Brain Res 100:103-117.

Nichols NR, Agolley D, Zieba M, and Bye N (2005) Glucocorticoid regulation of glial responses during hippocampal neurodegeneration and regeneration. Brain Res Brain Res Rev 48:287-301.
Peters CM, Rogers SD, Pomonis JD, Egnaczyk GF, Keyser CP, Schmidt JA, Ghilardi JR, Maggio JE, and Mantyh PW (2003) Endothelin receptor expression in the normal and injured spinal cord: potential involvement in injury-induced ischemia and gliosis. Exp Neurol 180:1-13.

Piette C, Munaut C, Foidart JM, and Deprez M (2006) Treating gliomas with glucocorticoids: from bedside to bench. Acta Neuropathol 112:651-664.

Planas AM, Solé S, and Justicia C (2001) Expression and activation of matrix metalloproteinase-2 and -9 in rat brain after transient focal cerebral ischemia. Neurobiol Dis 8:834-846

Rivera S, Ogier C, Jourquin J, Timsit S, Szklarczyk AW, Miller K, Gearing AJ, Kaczmarek L, and Khrestchatisky M (2002) Gelatinase B and TIMP-1 are regulated in a cell- and time-dependent manner in association with neuronal death and glial reactivity after global forebrain ischemia. Eur J Neurosci 15:19-32.

Rogers SD, Peters CM, Pomonis JD, Hagiwara H, Ghilardi JR, and Mantyh PW (2003) Endothelin B receptors are expressed by astrocytes and regulate astrocyte hypertrophy in the normal and injured CNS. Glia 41:180-190.

Rosell A and Lo EH (2008) Multiphasic roles for matrix metalloproteinases after stroke. Curr Opin Pharmacol 8:82-89.

Salvador E, Shityakov S, and Förster C (2014) Glucocorticoids and endothelial cell barrier function. Cell Tissue Res 355:597-605.

Shibata K, Komatsu C, Misumi Y, and Furukawa T (1995) Dexamethasone downregulates the expression of endothelin $\mathrm{B}$ receptor mRNA in the rat brain. Brain Res 692:71-78

Spataro L, Dilgen J, Retterer S, Spence AJ, Isaacson M, Turner JN, and Shain W (2005) Dexamethasone treatment reduces astroglia responses to inserted neuroprosthetic devices in rat neocortex. Exp Neurol 194:289-300.

Stokum JA, Gerzanich V, and Simard JM (2016) Molecular pathophysiology of cerebral edema. J Cereb Blood Flow Metab 36:513-538.

Takahashi T, Kimoto T, Tanabe N, Hattori TA, Yasumatsu N, and Kawato S (2002) Corticosterone acutely prolonged N-methyl-d-aspartate receptor-mediated $\mathrm{Ca}^{2+}$ elevation in cultured rat hippocampal neurons. J Neurochem 83:1441-1451.

Tenenbaum T, Matalon D, Adam R, Seibt A, Wewer C, Schwerk C, Galla HJ, and Schroten H (2008) Dexamethasone prevents alteration of tight junctionassociated proteins and barrier function in porcine choroid plexus epithelial cells after infection with Streptococcus suis in vitro. Brain Res 1229:1-17.

Unemura K, Kume T, Kondo M, Maeda Y, Izumi Y, and Akaike A (2012) Glucocorticoids decrease astrocyte numbers by reducing glucocorticoid receptor expression in vitro and in vivo. J Pharmacol Sci 119:30-39.

Wilhelmsson U, Li L, Pekna M, Berthold CH, Blom S, Eliasson C, Renner O, Bushong E, Ellisman M, Morgan TE, et al. (2004) Absence of glial fibrillary acidic protein and vimentin prevents hypertrophy of astrocytic processes and improves posttraumatic regeneration. $J$ Neurosci 24:5016-5021.

Wolburg H, Noell S, Mack A, Wolburg-Buchholz K, and Fallier-Becker P (2009) Brain endothelial cells and the glio-vascular complex. Cell Tissue Res 335:75-96.

Xiao L, Feng C, and Chen Y (2010) Glucocorticoid rapidly enhances NMDA-evoked neurotoxicity by attenuating the NR2A-containing NMDA receptor-mediated ERK1/2 activation. Mol Endocrinol 24:497-510.

Yan P, Xu J, Li Q, Chen S, Kim GM, Hsu CY, and Xu XM (1999) Glucocorticoid receptor expression in the spinal cord after traumatic injury in adult rats. $J$ Neurosci 19:9355-9363.

Yang JT, Lee TH, Lee IN, Chung CY, Kuo CH, and Weng HH (2011) Dexamethasone inhibits ICAM-1 and MMP-9 expression and reduces brain edema in intracerebral hemorrhagic rats. Acta Neurochir (Wien) 153:2197-2203.

Address correspondence to: Yutaka Koyama, Department of Pharmacology, Kobe Pharmaceutical University, 4-19-1, Motoyamakita, Higashinada, Kobe 658-8558, Japan. E-mail: koyama-y@kobepharma-u.ac.jp 